\title{
Towards high-efficiency CZTS solar cell through buffer layer optimization
}

\author{
Farjana Akter Jhuma ${ }^{1} \cdot$ Marshia Zaman Shaily ${ }^{1} \cdot$ Mohammad Junaebur Rashid $^{1}$
}

Received: 18 April 2018 / Accepted: 8 February 2019 / Published online: 13 February 2019

(c) The Author(s) 2019

\begin{abstract}
$\mathrm{Cu}_{2} \mathrm{ZnSnS}_{4}$ (CZTS)-based solar cells show a promising performance in the field of sunlight-based energy production system. To increase the performance of CZTS-based solar cell, buffer layer optimization is still an obstacle. In this work, numerical simulations were performed on structures based on CZTS absorber layer, ZnO window layer, and transparent conducting layer n-ITO with different buffer layers using SCAPS-1D software to find a suitable buffer layer. Cadmium sulfide (CdS), zinc sulfide $(\mathrm{ZnS})$ and their alloy cadmium zinc sulfide $\left(\mathrm{Cd}_{0.4} \mathrm{Zn}_{0.6} \mathrm{~S}\right)$ were used as potential buffer layers to investigate the effect of buffer thickness, absorber thickness and temperature on open-circuit voltage $\left(V_{\mathrm{oc}}\right)$, short-circuit current $\left(J_{\mathrm{sc}}\right)$, fill factor (FF) and efficiency $(\eta)$ of the solar cell. The optimum efficiencies using these three buffer layers are around $11.20 \%$. Among these three buffers, $\mathrm{Cd}_{0.4} \mathrm{Zn}_{0.6} \mathrm{~S}$ is more preferable as $\mathrm{CdS}$ suffers from toxicity problem and $\mathrm{ZnS}$ shows drastic change in performance parameters. The simulation results can give important guideline for the fabrication of high-efficiency CZTS solar cell.
\end{abstract}

Keywords CZTS $\cdot$ SCAPS-1D $\cdot \mathrm{CdS} \cdot \mathrm{ZnS} \cdot \mathrm{Cd}_{0.4} \mathrm{Zn}_{0.6} \mathrm{~S}$

\section{Introduction}

The green, clean, renewable and sustainable energy source, sun has a very high potential to meet up the electricity demand of the world and the sunlight can directly be converted to electricity through solar cell using the principle known as photovoltaic (PV) effect. To obtain low cost and high-efficiency solar cell, researchers are working on many different solar materials such as $\mathrm{Si}, \mathrm{CdTe}, \mathrm{Cu}(\mathrm{In}, \mathrm{Ga})$ $\mathrm{Se}_{2}$ (CIGS), $\mathrm{Cu}_{2} \mathrm{ZnSnS}_{4}$ (CZTS), CZTSSe and organic resources [1,2].

The most widely used Si-based solar cell exhibits high conversion efficiency (up to $24.5 \%$ at the University of New South Wales) [3]. However, it suffers from low throughput and high cost, therefore, could not affect the world's energy

Farjana Akter Jhuma

jhuma.univdhaka@gmail.com

Marshia Zaman Shaily

marshiazaman@gmail.com

Mohammad Junaebur Rashid

mjrashid@du.ac.bd

1 Department of Electrical and Electronic Engineering, University of Dhaka, Dhaka 1000, Bangladesh market [4]. On the other hand, CIGS and CdTe offer high efficiencies (around $21 \%$ and 21\%, respectively) for which they attracted the researchers for the last few years [5]. The main problem with these two materials is the toxicity of the constituent materials cadmium and selenium and also the less availability of tellurium and indium on earth [6]. To meet up the problems, an alternative material, CZTS has drawn the attraction with good advantages over CIGS and CdTe. During last few years, a good amount of researches had been done to improve the solar cell efficiency using CZTS absorber layer [7]. Wei Wang et al. presented a record cell efficiency of around $12.6 \%$ using a hydrazine pure solution approach for $\mathrm{Cu}_{2} \mathrm{ZnSnS}_{4}$-based solar cell [8].

The material CZTS is a quaternary semiconductor with two different crystal structures stannite and kesterite. Kesterite structure shows more stability than stannite structure [9]. One important advantage of CZTS is that it consists of earthabundant materials which are non-toxic. Thus, CZTS offers lower cost in comparison with other thin-film solar cell that makes it more promising in PV technology. CZTS shows excellent photovoltaic properties such as a direct bandgap with bandgap energy of 1.45-1.6 eV and absorption coefficient over $1 \times 10^{4} \mathrm{~cm}^{-1}[10]$. CZTS can be fabricated using 
different processes such as sputtering, evaporation, spray pyrolysis, electrodeposition, sol-gel technique, etc. [11].

Though CZTS has become a good choice as solar cell material, buffer layer optimization is still an issue for its progress. The buffer layer provides band alignment between the CZTS and window layer and also reduces defects and interfacial strain due to the window layer [12]. Cadmium sulfide (CdS) can be used as a prominent buffer as it improves interface with the absorber CZTS and has higher transmission in the blue wavelength region. It has a bandgap of $2.42 \mathrm{eV}$ and absorbs photons with wavelength lower than $590 \mathrm{~nm}$ covering 24\% of the solar spectrum [13]. However, CdS contains large amount of $\mathrm{Cd}$ which is toxic and also produces a large amount of wastage during the deposition processes. To avoid this problem, an environment friendly material zinc sulfide $(\mathrm{ZnS})$ can also be used as an alternative buffer layer. ZnS has a higher bandgap of $3.5 \mathrm{eV}$ compared to $\mathrm{CdS}$ which results in less absorption of low-wavelength photons. It also produces better interface with CZTS creating a potential barrier to separate the electron-hole pair [14].

$\mathrm{Cd}_{1-x} \mathrm{Zn}_{x} \mathrm{~S}$ is another buffer layer which is promising as its bandgap can be varied between $2.42 \mathrm{eV}(\mathrm{CdS})$ and $3.5 \mathrm{eV}$ $(\mathrm{ZnS})$. The bandgap of $\mathrm{Cd}_{1-x} \mathrm{Zn}_{x} \mathrm{~S}$ for different $\mathrm{Zn}$ composition $(x)$ can be calculated using the following equation which is a modified Vegard's law [15]:

$E_{g}\left(\mathrm{Cd}_{1-x} \mathrm{Zn}_{x} \mathrm{~S}\right)=2.566+0.041 x+1.086 x^{2}(\mathrm{eV})$.

With increasing $\mathrm{Zn}$ concentration, bandgap increases letting lower wavelength photon through the device. Thus, instead of $\mathrm{CdS}, \mathrm{Cd}_{1-x} \mathrm{Zn}_{x} \mathrm{~S}$ can be used to obtain a more transparent window in the short-wavelength region, already demonstrated by Oladeji et al. [16]. On the other hand, the grain size decreases as $\mathrm{Zn}$ concentration increases in $\mathrm{Cd}_{1-x} \mathrm{Zn}_{x} \mathrm{~S}$ [17]. It turns out that for a $\mathrm{Zn}$ content of $x=0.6$ in $\mathrm{Cd}_{1-x} \mathrm{Zn}_{x} \mathrm{~S}$, highest current density can be achieved which leads to a significant enhancement in the solar cell efficiency [15]. Therefore, in this simulation study, $60 \% \mathrm{Zn}$ is used in $\mathrm{Cd}_{1-x} \mathrm{Zn}_{x} \mathrm{~S}$ and the bandgap of $2.98 \mathrm{eV}$ is calculated using Eq. (1).

The main objective of this work is to offer a CZTS solar cell with high efficiency using a suitable buffer layer. For this reason, three CZTS solar cell device models using three different buffer layers such as $\mathrm{CdS}, \mathrm{ZnS}$, and $\mathrm{Cd}_{0.4} \mathrm{Zn}_{0.6} \mathrm{~S}$ were numerically analyzed using SCAPS-1D to obtain the solar cell performance parameters. Different solar cell parameters $V_{\text {oc }}, J_{\text {sc }}$, fill factor (FF), and efficiency $(\eta)$ were observed and performance analysis was conducted between the three structures CdS/CZTS, ZnS/CZTS and $\mathrm{Cd}_{0.4} \mathrm{Zn}_{0.6} \mathrm{~S} / \mathrm{CZTS}$.

\section{Methodology and device structure}

SCAPS-1D, a one-dimensional solar cell simulation software developed at the Department of Electronics and Information Systems (EIS), University of Gent, Belgium, was used for numerically analyzing the solar cell. Up to seven different layers can be added in the cell definition panel of the software which makes it more suitable for solar cell simulation. Physical properties such as bandgap, electron affinity, dielectric permittivity, etc., for different layers can be modified in the layer properties panel which helps to achieve the desired structure. The necessary working point specification can be indicated in the action panel. The software supports grading of all physical parameters and also specification of properties of front and back contact. A large number of AC and DC electrical measurements including short-circuit current density $\left(J_{\mathrm{sc}}\right)$, fill factor $(\mathrm{FF})$, open-circuit voltage $\left(V_{\text {oc }}\right)$, conversion efficiency $(\eta)$, quantum efficiency $(\mathrm{QE})$, spectral response, generation and recombination profile can be calculated as well as displayed using the software SCAPS-1D, compared to other simulation software [18].

Figure 1 shows the solar cell structure used in this study. The structure started with soda lime glass substrate. A thin $\mathrm{MoS}_{2}$ layer of thickness of $100 \mathrm{~nm}$ to avoid high series resistance was used over the absorber layer, as this layer can be experimentally formed by the reaction of Mo back contact with sulfur contained in the absorber precursor ( $\mathrm{ZnS}$ or $\mathrm{SnS}$ ) in the case of CZTS solar cell [19]. The next layer was CZTS absorber layer in which most of the incident photons were absorbed to produce electron-hole pairs. $\mathrm{CdS}$ or $\mathrm{ZnS}$ or $\mathrm{Cd}_{0.4} \mathrm{Zn}_{0.6} \mathrm{~S}$ buffer layer was used after that to provide the band alignment between CZTS and following window layer. Afterwards, less costly and available zinc oxide $(\mathrm{ZnO})$ of

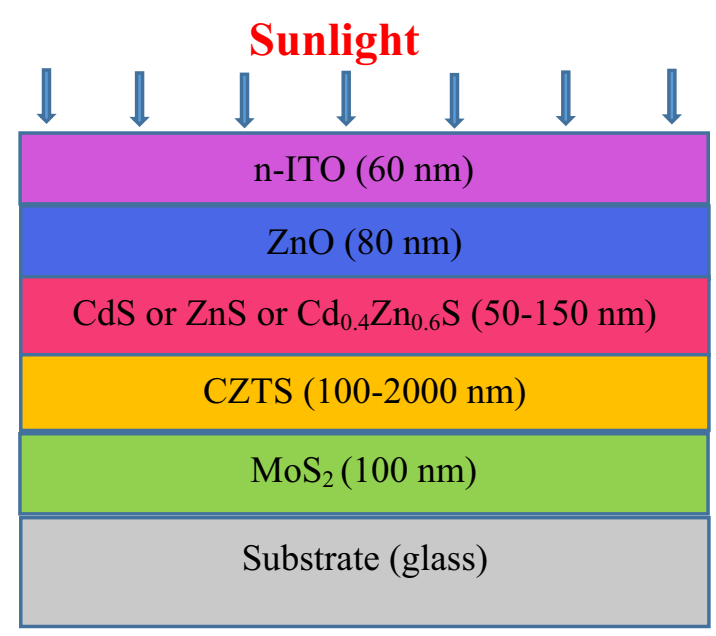

Fig. 1 Structure of CZTS thin-film solar cell 
thickness of $80 \mathrm{~nm}$ was used for the window layer over the buffer layer which enhances light scattering to enable the efficient use of sun light to maximize the number of incident photons to the buffer and absorber layers [20]. Finally, a transparent conducting film n-type indium tin oxide (n-ITO) of thickness of $60 \mathrm{~nm}$ was used to provide a high mobility leading to an increase in visible absorption to obtain a lower sheet resistance [21].

The illumination of light was through the side of n-ITO layer with "Air mass 1.5 global" spectrum with $1000 \mathrm{~W} /$ $\mathrm{m}^{2}$ light power at $25{ }^{\circ} \mathrm{C}$. In this work, the effect of series or shunt resistance was not considered. Two types of single layer defect were introduced in the absorber layer and buffer layer for the simulations. The values of the physical parameters used in this study are all taken from experimental study, different literatures or reasonable estimates [15, 22-25] which are summarized in Table 1.

The observation of CZTS solar cell performances was performed in three different steps. In the first step, the buffer layer's thickness was varied from 50 to $150 \mathrm{~nm}$ with equal steps of $25 \mathrm{~nm}$ while keeping the absorber layer fixed at $2000 \mathrm{~nm}$. The optimum thickness of the buffer layer was determined and then using it, the performance parameters were calculated and presented for each structure. In the next step, the buffer layer was fixed at its optimum thickness and the CZTS absorber layer was varied for the range of 100-2000 nm with a step size of $400 \mathrm{~nm}$. Then, using the obtained CZTS optimum thickness for their respective buffer layer, the performance parameters were simulated and displayed in this case. Finally, the effect of temperature was observed for each structure by varying the temperature from 290 to $350 \mathrm{~K}$ with equal steps of $10 \mathrm{~K}$. It is to be mentioned that for each step the other layers thickness and the material properties were fixed at their respective values.

\section{Results and discussion}

\section{Effect of buffer layer's thickness}

To investigate the effect of buffer layer's thickness, simulations were done on the structure shown in Fig. 1 with different buffer layers. As already mentioned in Sect. 2, the buffer layer thickness was varied from 50 to $150 \mathrm{~nm}$ with a fixed CZTS layer of $2000 \mathrm{~nm}$ for the first steps of simulation. A single acceptor-type defect with defect density of $6 \times 10^{16} \mathrm{~cm}^{-3}$ was introduced in the buffer layer [25]. Figure 2 shows the variation of solar cell parameters such as open-circuit voltage $\left(V_{\mathrm{oc}}\right)$, short-circuit current density $\left(J_{\mathrm{sc}}\right)$, fill factor $(\mathrm{FF})$ and efficiency $(\eta)$ with the increase in buffer layer thickness. In Fig. 2 (for all graphs), the black line shows the variations for $\mathrm{ZnS}$, the red line (behind the blue line) for $\mathrm{CdS}$ and the blue line for $\mathrm{Cd}_{0.4} \mathrm{Zn}_{0.6} \mathrm{~S}$ buffer. In Fig. 2a, the $V_{\text {oc }}$ vs. buffer layer thickness is shown where an increasing trend is found for $\mathrm{ZnS}$ buffer after $100 \mathrm{~nm}$ whereas for $\mathrm{CdS}$ and $\mathrm{Cd}_{0.4} \mathrm{Zn}_{0.6} \mathrm{~S}$, buffer layer change is too small to be found. ZnS buffer layer has higher bandgap with respect to the other two buffer layer for which it acquires larger $V_{\text {oc }}$ as larger bandgap decreases diode saturation current. As buffer thickness increases, the amount of photons absorbed outside the hole diffusion length region increases which lowers the recombination rate and thus increases $V_{\text {oc }}$ [26]. Next, the change in $J_{\mathrm{sc}}$ is shown in Fig. $2 \mathrm{~b}$ where a decreasing curve is found for $\mathrm{ZnS}$ buffer after about $110 \mathrm{~nm}$, on the other hand, curves for other two buffers remain almost flat. When bandgap of a material becomes larger, photons can not achieve the required amount of energy to absorb higher wavelength photons and create electron-hole pair and so result in lower short-circuit current density. That is why

Table 1 The physical parameters of different layer

\begin{tabular}{|c|c|c|c|c|c|c|c|}
\hline Parameters & $\mathrm{MoS}_{2}$ & CZTS & $\mathrm{CdS}$ & $\mathrm{ZnS}$ & $\mathrm{Cd}_{0.4} \mathrm{Zn}_{0.6} \mathrm{~S}$ & $\mathrm{i}-\mathrm{ZnO}$ & n-ITO \\
\hline Thickness (nm) & 100 & $100-2000$ & $50-150$ & $50-150$ & $50-150$ & 80 & 60 \\
\hline Bandgap (eV) & 1.7 & 1.5 & 2.4 & 3.5 & 2.98 & 3.3 & 3.6 \\
\hline Electron affinity $(\mathrm{eV})$ & 4.2 & 4.5 & 4.5 & 4.5 & 4.2 & 4.6 & 4.1 \\
\hline Dielectric permittivity & 13.6 & 10 & 10 & 10 & 9.4 & 9 & 10 \\
\hline $\mathrm{CB}$ effective density of states $\left(\mathrm{cm}^{-3}\right)$ & $2.2 \times 10^{18}$ & $2.2 \times 10^{18}$ & $2.2 \times 10^{18}$ & $1.8 \times 10^{18}$ & $2.2 \times 10^{18}$ & $2.2 \times 10^{18}$ & $2.2 \times 10^{18}$ \\
\hline VB effective density of states $\left(\mathrm{cm}^{-3}\right)$ & $1.8 \times 10^{19}$ & $1.8 \times 10^{19}$ & $1.8 \times 10^{19}$ & $1.8 \times 10^{19}$ & $1.8 \times 10^{19}$ & $1.8 \times 10^{19}$ & $1.8 \times 10^{19}$ \\
\hline Electron thermal velocity $\left(\mathrm{cm} \mathrm{s}^{-1}\right)$ & $1 \times 10^{7}$ & $1 \times 10^{7}$ & $1 \times 10^{7}$ & $1 \times 10^{7}$ & $1 \times 10^{7}$ & $1 \times 10^{7}$ & $1 \times 10^{7}$ \\
\hline Hole thermal velocity $\left(\mathrm{cm}^{-1}\right)$ & $1 \times 10^{7}$ & $1 \times 10^{7}$ & $1 \times 10^{7}$ & $1 \times 10^{7}$ & $1 \times 10^{7}$ & $1 \times 10^{7}$ & $1 \times 10^{7}$ \\
\hline Electron mobility $\left(\mathrm{cm}^{2} / V_{\mathrm{s}}\right)$ & 100 & 100 & 100 & 100 & 270 & 100 & 50 \\
\hline Hole mobility $\left(\mathrm{cm}^{2} / V_{\mathrm{s}}\right)$ & 25 & 25 & 25 & 25 & 27 & 25 & 75 \\
\hline Shallow uniform donor density, $\mathrm{N}_{\mathrm{D}}\left(\mathrm{cm}^{-3}\right)$ & 0 & $1 \times 10^{1}$ & $1 \times 10^{18}$ & $5 \times 10^{15}$ & $1 \times 10^{17}$ & $1 \times 10^{18}$ & $1 \times 10^{19}$ \\
\hline Shallow uniform acceptor density, $N_{\mathrm{D}}\left(\mathrm{cm}^{-3}\right)$ & $1 \times 10^{16}$ & $2 \times 10^{14}$ & 0 & $1 \times 10^{1}$ & 0 & 0 & 0 \\
\hline Defect type & - & Donor & Acceptor & Acceptor & Acceptor & - & - \\
\hline Defect density $\left(\mathrm{cm}^{-3}\right)$ & - & $1 \times 10^{13}$ & $6 \times 10^{16}$ & $6 \times 10^{16}$ & $6 \times 10^{16}$ & - & - \\
\hline
\end{tabular}




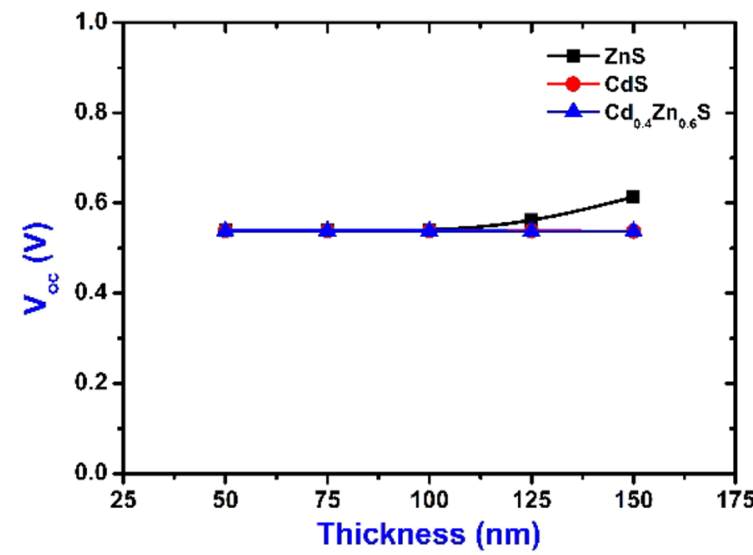

(a)

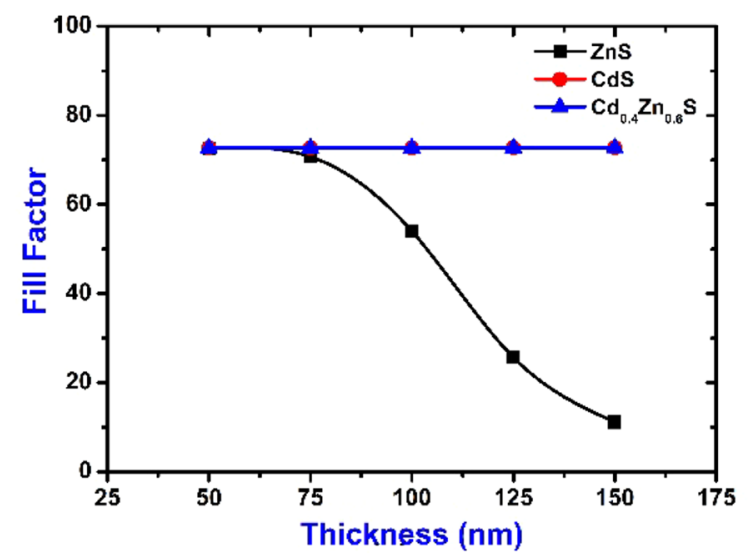

(c)

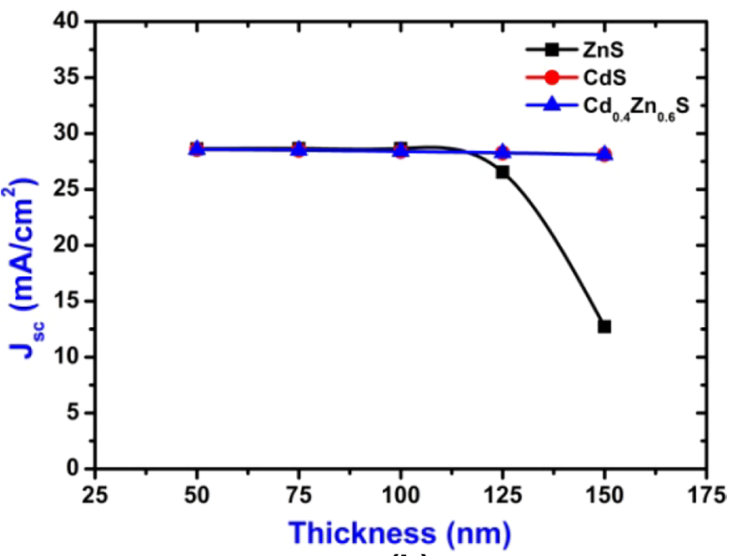

(b)

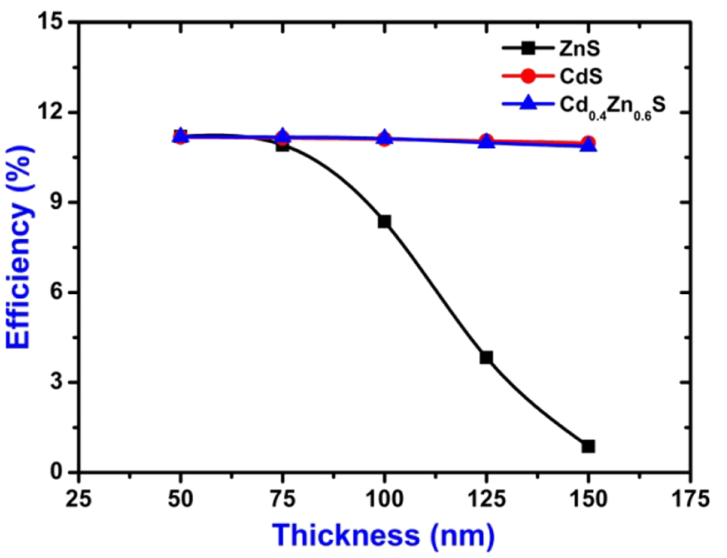

(d)

Fig. 2 a $V_{\mathrm{oc}}$ vs. buffer layer thickness. b $J_{\mathrm{sc}}$ vs. buffer layer thickness. c Fill factor vs. buffer layer thickness. d Efficiency vs. buffer layer thickness

$\mathrm{ZnS}$ buffer layer possesses lower value of $J_{\text {sc }}$ than the two other buffer layers [26]. The decrease in short-circuit density results due to the less production of electron-hole pair as less number of electron-hole pair can reach the absorber layer with increase in buffer layer thickness [22]. In the case of fill factor, the decreasing behavior for $\mathrm{ZnS}$ can be seen around $65 \mathrm{~nm}$ in Fig. 2c whereas the fill factor for $\mathrm{CdS}$ and $\mathrm{Cd}_{0.4} \mathrm{Zn}_{0.6} \mathrm{~S}$ do not show any change. The fill factor of $\mathrm{ZnS}$ decreases from $65 \mathrm{~nm}$ hereafter due to the effect of series resistance which increase with thickness and reduces the maximum achievable power output [27]. Finally, Fig. 2d shows the efficiency curves for the different buffer layers which follow the trend of the fill factor. The efficiency of the solar cell for $\mathrm{ZnS}$ buffer layers falls to almost $1 \%$ at $150 \mathrm{~nm}$ thickness whereas for $\mathrm{CdS}$ and $\mathrm{Cd}_{0.4} \mathrm{Zn}_{0.6} \mathrm{~S}$ buffers the efficiencies decrease slightly. The efficiencies are changed due to the combined effect of $V_{\mathrm{oc}}, J_{\mathrm{sc}}$ and fill factor. Note that the solar cell performance can also decrease due to the additional trapping layers created by the defect, which can trap the incident photon [28]. The obtained optimum efficiencies for $\mathrm{CdS}, \mathrm{ZnS}$ and $\mathrm{Cd}_{0.4} \mathrm{Zn}_{0.6} \mathrm{~S}$ buffers are $11.18 \%, 11.20 \%$ and $11.19 \%$, respectively. The suitable thickness of $\mathrm{CdS}$ and $\mathrm{Cd}_{0.4} \mathrm{Zn}_{0.6} \mathrm{~S}$ buffer layers is in the range of $50-150 \mathrm{~nm}$, and for $\mathrm{ZnS}$ it is the range of $50-75 \mathrm{~nm}$.

\section{Effect of CZTS absorber layer's thickness}

The effect of CZTS thickness on solar cell performance was observed through simulations in three different structures CdS/CZTS, ZnS/CZTS and $\mathrm{Cd}_{0.4} \mathrm{Zn}_{0.6} \mathrm{~S} / \mathrm{CZTS}$. For each simulation, the thickness of CZTS was varied from 100 to $2000 \mathrm{~nm}$ with a fixed buffer layer thickness of $50 \mathrm{~nm}$ at a temperature of $300 \mathrm{~K}$. A single donor-type defect with a defect density of $1 \times 10^{13} \mathrm{~cm}^{-3}$ was introduced in the CZTS layer [25]. Figure 3a-d shows the variation of open-circuit voltage $\left(V_{\text {oc }}\right)$, short-circuit current density $\left(J_{\mathrm{sc}}\right)$, fill factor (FF) and efficiency $(\eta)$, respectively, with increasing absorber layer's thickness. In each figure, the black curve shows the variation for ZnS/CZTS structure, the red curve for CdS/CZTS and the blue curve indicates the $\mathrm{Cd}_{0.4} \mathrm{Zn}_{0.6} \mathrm{~S} / \mathrm{CZTS}$ structure. It is evident from Fig. 3 that all the parameters such as $V_{\mathrm{oc}}, J_{\mathrm{sc}}, \mathrm{FF}$ and $\eta$ are low at 


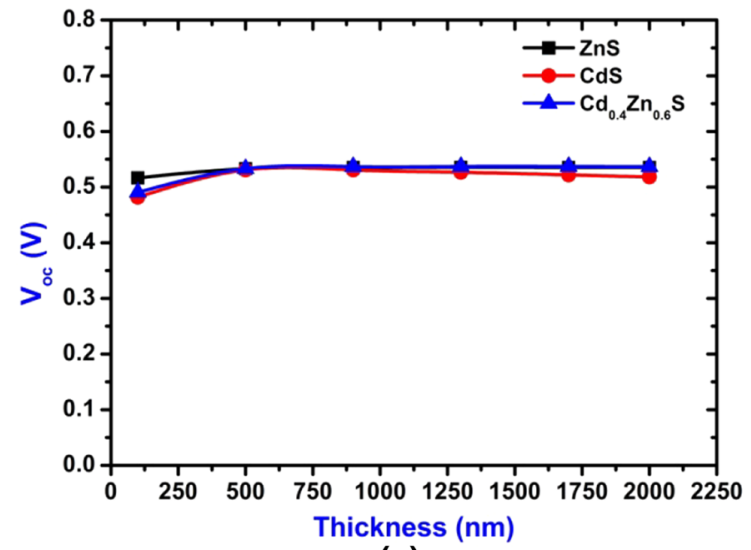

(a)

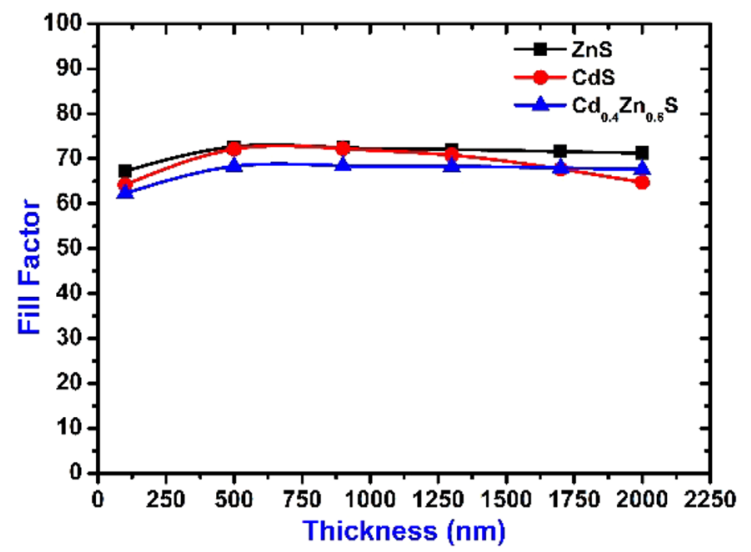

(c)

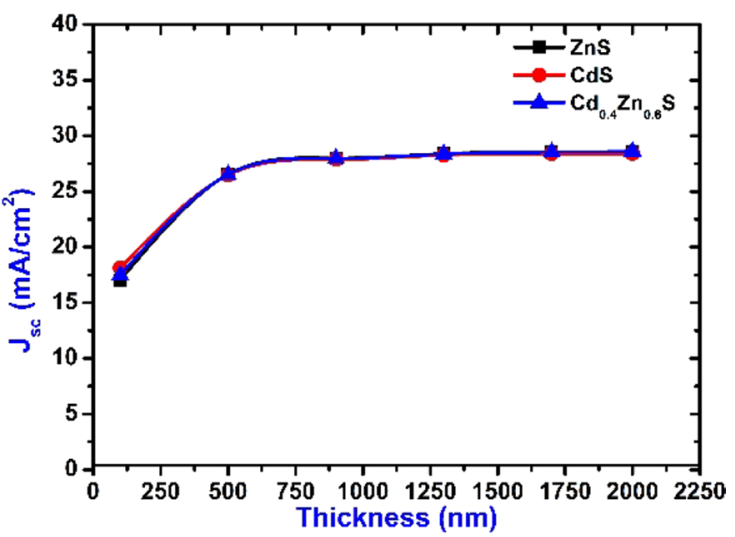

(b)

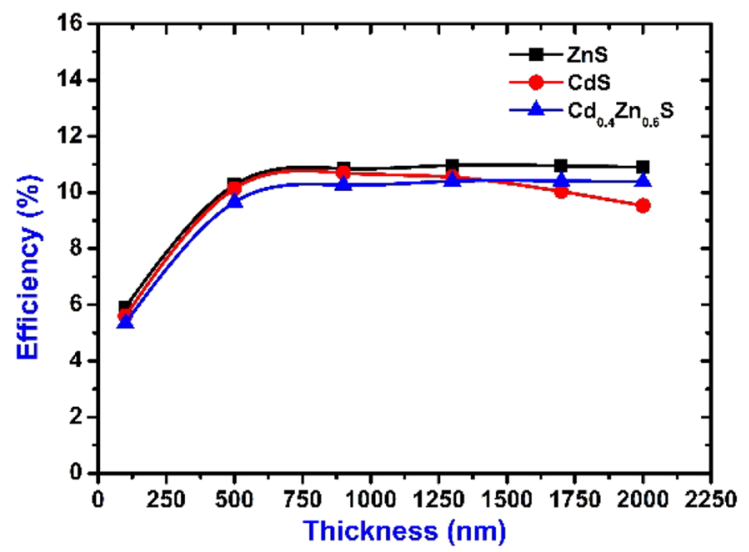

(d)

Fig. 3 a $V_{\text {oc }}$ vs. absorber layer thickness. b $J_{\text {sc }}$ vs. absorber layer thickness. c Fill factor vs. absorber layer thickness. d Efficiency vs. absorber layer thickness

lower thickness of CZTS layer (nearly 250-550 nm) which results due to the high recombination of the photo-generated carriers which recombines before reaching the buffer layer/ CZTS layer interface [25]. All the parameters then start to increase with the increase in CZTS thickness because the thicker CZTS layer will absorb more photons and generates more electron-hole pairs [25]. But after a certain thickness $(900 \mathrm{~nm}, 1300 \mathrm{~nm}$, and $1700 \mathrm{~nm}$ for CdS/CZTS, ZnS/ CZTS and $\mathrm{Cd}_{0.4} \mathrm{Zn}_{0.6} \mathrm{~S} / \mathrm{CZTS}$ structures, respectively) the performance again starts to deteriorate as the CZTS layer crosses its minority carrier diffusion length. The decreasing nature can be observed for CdS/CZTS structure clearly whereas for other two structures the decrement is very small to be observed. The incident photons absorbed outside the minority carrier diffusion length are lost by recombination and thus decreases the solar cell performance. The best efficiencies for CdS/CZTS, ZnS/CZTS and $\mathrm{Cd}_{0.4} \mathrm{Zn}_{0.6} \mathrm{~S} / \mathrm{CZTS}$ structures were found $10.69 \%$ at $900 \mathrm{~nm}, 10.96 \%$ at $1300 \mathrm{~nm}$ and $10.93 \%$ at $1700 \mathrm{~nm}$, respectively.

\section{Effect of working temperature}

In this section, the effect of temperature was observed for each structure by varying it from $290 \mathrm{~K}$ to $350 \mathrm{~K}$. For CdS/ CZTS, ZnS/CZTS and $\mathrm{Cd}_{0.4} \mathrm{Zn}_{0.6} \mathrm{~S} / \mathrm{CZTS}$ structures, the CZTS absorber layer's thickness was kept fixed at $900 \mathrm{~nm}$, $1300 \mathrm{~nm}$ and $1700 \mathrm{~nm}$, respectively, while the buffer layer's thickness was fixed at $50 \mathrm{~nm}$ for every structure. The alteration of open-circuit voltage $\left(V_{\mathrm{oc}}\right)$, short-circuit current density $\left(J_{\mathrm{sc}}\right)$, fill factor $(\mathrm{FF})$ and efficiency $(\eta)$ with increasing temperature is shown Fig. 4 where the black, red and blue lines represent the changes in ZnS/CZTS, CdS/CZTS and $\mathrm{Cd}_{0.4} \mathrm{Zn}_{0.6} \mathrm{~S} / \mathrm{CZTS}$ structures separately. When the temperature increases, there is an increase in the energy of electrons thus the bandgap of the material decreases. The electrons gaining extensive energy thus recombine with other holes. As a result, recombination rate of internal carrier increases resulting in decreasing $V_{\mathrm{oc}}$ and efficiency [29]. This effect can be understood quite well from Fig. 4. In Fig. 4a, $V_{\text {oc }}$ decreases almost linearly with increasing temperature. This is due to the reverse saturation current which increases with 


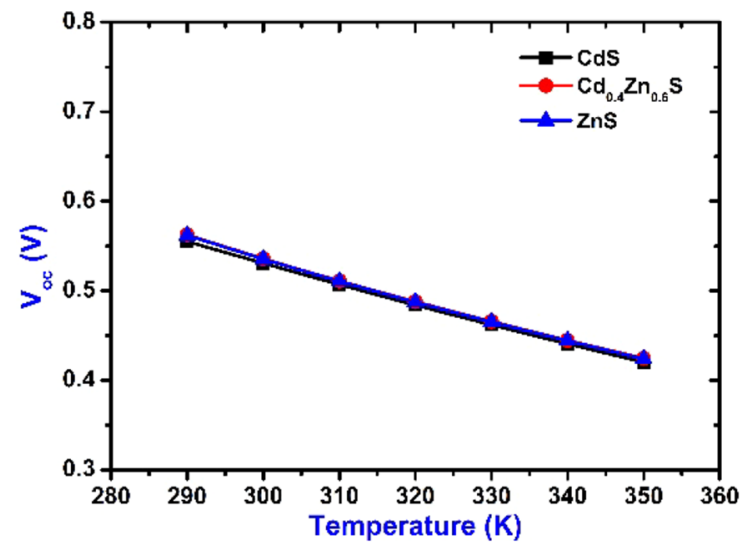

(a)

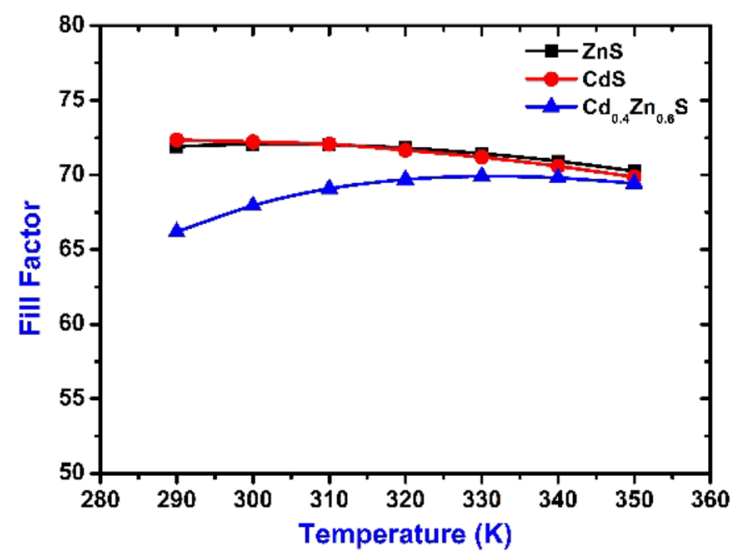

(c)

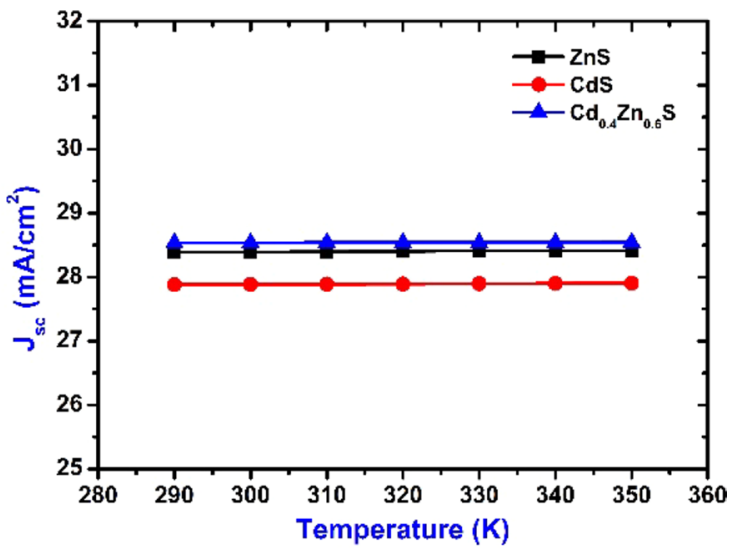

(b)

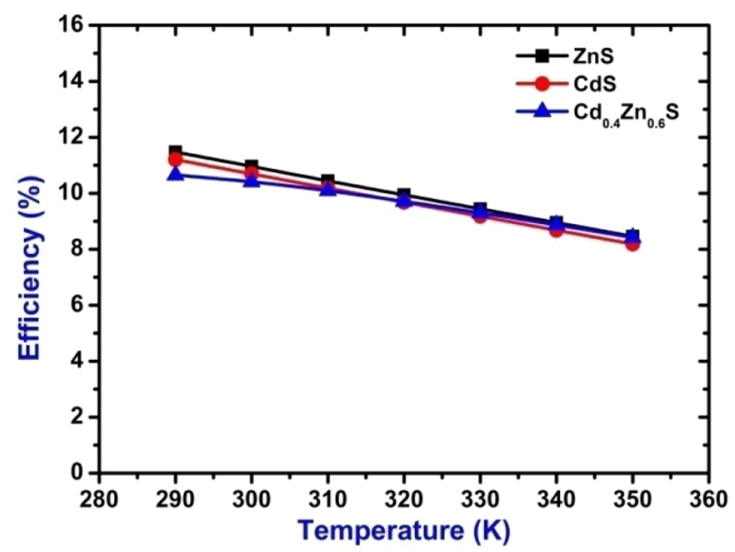

(d)

Fig. 4 a $V_{\mathrm{oc}}$ vs. temperature. $\mathbf{b} J_{\mathrm{sc}}$ vs. temperature. c Fill factor vs. temperature. d Efficiency vs. temperature

temperature and reduces the saturation current to decrease the open-circuit voltage [22]. The change of $J_{\mathrm{sc}}$ is very small with increasing temperature shown in Fig. $4 \mathrm{~b}$ as recombination process starts to dominate [29]. Whereas the fill factor first increases with temperature as the resistance effect decreases. But it decreases for higher temperature due to light-induced degradation which can be seen from Fig. 4c [29]. Finally, from Fig. 4d, the effect of increase in temperature on solar cell efficiency can be observed which shows a decreasing behavior due to the combined effect of $V_{\mathrm{oc}}, J_{\mathrm{sc}}$ and fill factor. From the simulation, the best efficiencies for CdS/CZTS, ZnS/CZTS and $\mathrm{Cd}_{0.4} \mathrm{Zn}_{0.6} \mathrm{~S} / \mathrm{CZTS}$ were found $11.20 \%, 11.47 \%$ and $11.58 \%$, respectively, at a temperature of $290 \mathrm{~K}$.

\section{Conclusion}

In this work, numerical simulations were performed for CZTS solar cell using three different buffer layers such as $\mathrm{CdS}, \mathrm{ZnS}$, and $\mathrm{Cd}_{0.4} \mathrm{Zn}_{0.6} \mathrm{~S}$ and the performance parameters were observed by varying buffer layer thickness, absorber layer thickness and temperature. The buffer layer thickness for all these three types was found $50 \mathrm{~nm}$ to obtain high efficiency CZTS solar cell. Among them the CdS buffer layer used in the CZTS solar cell exhibited higher efficiency (11.20\%). In all cases performance parameters are affected significantly with the increased buffer layer. Because the loss of incident photons increases with increased buffer thickness which results in lower short circuit density leading to lower efficiency of the solar cell. The lower limit of thickness of CZTS absorber layer was obtained $500 \mathrm{~nm}$ to avoid the recombination of photogenerated carriers for all three buffer layers. In contrast the higher limit of thickness of CZTS absorber layer were found $1000 \mathrm{~nm}, 1400 \mathrm{~nm}$ and $1800 \mathrm{~nm}$ respectively for $\mathrm{CdS}, \mathrm{ZnS}$ and $\mathrm{Cd}_{0.4} \mathrm{Zn}_{0.6} \mathrm{~S}$ buffer layers to avoid the effect of minority carrier recombination. The best obtained efficiency (10.69\%) was found for 900 $\mathrm{nm}$ thick CZTS layer using CdS buffer layer. The effect of temperature in CZTS solar cell was also important. In all cases (using different buffer layers) the efficiency decreased if we go beyond $290 \mathrm{~K}$, as in higher temperature there is an 
enhancement of internal recombination of photogenerated carriers. The optimization of this study can lead to fabrication of high-efficiency CZTS solar cell.

Open Access This article is distributed under the terms of the Creative Commons Attribution 4.0 International License (http://creativeco mmons.org/licenses/by/4.0/), which permits unrestricted use, distribution, and reproduction in any medium, provided you give appropriate credit to the original author(s) and the source, provide a link to the Creative Commons license, and indicate if changes were made.

\section{References}

1. Bagher, A.M., Vahid, M.M.A., Mohsen, M.: Types of solar cells and application. Am. J. Opt. Photon. 3(5), 94-113 (2015)

2. Rao, S., Morankar, A., Verma, H., Goswami, P.: Emerging photovoltaics: organic, copper zinc tin sulphide, and perovskite-based solar cells. J. Appl. Chem. 2016, 3971579 (2016)

3. Zhao, J., Wang, A., Green, M.A.: $245 \%$ Efficiency silicon PERT cells on MCZ substrates and $247 \%$ efficiency PERL cells on FZ substrates. Prog. Photovolt. Res. Appl. 7(6), 471-474 (1999)

4. Kaur, M., Singh, H.: A review: comparison of silicon solar cells and thin film solar cells. Int. J. Core Eng. Manag. (IJCEM) 3(2), 15-23 (2016)

5. Green, M.A., Emery, K., Hisikawa, Y., Warta, W., Dunlop, E.D.: Solar cell efficiency tables (Version 49). Prog. Photovolt. Res. Appl. 2017(25), 3-13 (2016)

6. Yeh, M.Y., Lei, P.H., Lin, S.H., Yang, C.D.: Copper-Zinc-TinSulfur thin film using spin-coating technology. Materials 9(7), 526 (2016)

7. Katagiri, H., Jimbo, K., Maw, W.S., Takeuchi, A.: Development of CZTS based thin film solar cells. Thin Solid Films 517(7), 2455-2460 (2009)

8. Wang, W., Winkler, M.T., Gunawan, O., Gokmen, T., Todorov, T.K., Zhu, Y., Mitzi, D.B.: Device characteristics of CZTSSe thinfilm solar cells with $12.6 \%$ efficiency. Adv. Energy Mater. 4(7), 1301465 (2014)

9. Maeda, T., Nakamura, S., Wada, T.: Electronic structure and phase stability of in-free photovoltaic semiconductors, $\mathrm{Cu}_{2} \mathrm{ZnSnSe}_{4}$ and $\mathrm{Cu}_{2} \mathrm{ZnSnS}_{4}$ by first-principles calculation. MRS. Proc. 1165, https ://doi.org/10.1557/PROC-1165-M04-03 (2011)

10. Hironori, K., Kotoe, S., Tsukasa, W., Hiroyuki, S., Tomomi, K., Shinsuke, M.: Development of thin film solar cell based on $\mathrm{Cu}_{2} \mathrm{ZnSnS}_{4}$ thin films. Sol. Energy Mater. Sol. Cells 65(1-4), 141-148 (2001)

11. Suryawanshi, M.P., Agawane, G.L., Bhosale, S.M., Shin, S.W., Patil, P.S., Kim, J.H., Moholkar, A.V.: CZTS based thin film solar cells: a status review. Mater. Technol. 28(1-2), 98-109 (2013)

12. Eisele, W., Ennaoui, A., Schubert-Bischoff, P., Giersig, M., Pettenkofer, C., Krauser, J., Lux-Steiner, M., Zweigart, S., Karg, F.: XPS, TEM and NRA investigations of $\mathrm{Zn}(\mathrm{Se}, \mathrm{OH}) / \mathrm{Zn}(\mathrm{OH}) 2$ films on $\mathrm{Cu}(\mathrm{In}, \mathrm{Ga})(\mathrm{S}, \mathrm{Se}) 2$ substrates for highly efficient solar cells. Sol. Energy Mater. Sol. Cell. 7(1-2), 17-26 (2003)

13. Nguyen, M., Ernits, K., Tai, K.F., Ng, C.F., Pramana, S.S., Sasangka, W.A., Batabyal, S.K., Holopainen, T., Meissner, D., Neisser, A., Wong, L.H.: ZnS buffer layer for $\mathrm{Cu}_{2} \mathrm{ZnSn}(\mathrm{SSe})_{4}$ monograin layer solar cell. Sol. Energy 111, 344-349 (2015)
14. Gunavathy, K.V., Parthibaraj, V., Rangasami, C., Tamilarasan, K.: Prospects of alternate buffer layers for CZTS based thin films solar cells from numerical analysis - a review. South Asian J. Eng. Technol. 2(16), 88-96 (2016)

15. Ferdaous, M.T., Islam, M.F., Haque, K.A.S.M.E., Amin, N.: Numerical analysis of ultra-thin high efficiency $\mathrm{Cd}_{1-\mathrm{x}} \mathrm{Zn}_{\mathrm{x}} \mathrm{S} /$ $\mathrm{Cd}_{1-\mathrm{x}} \mathrm{Zn}_{\mathrm{x}}$ Te solar cell. Electr. Electron. Eng. 5(A), 14-18 (2015)

16. Oladeji, I.O., Chow, L., Ferekides, C.S., Viswanathan, V., Zhao, Z.: Metal/CdTe/CdS/Cd ${ }_{1-x} \mathrm{Zn}_{\mathrm{x}} \mathrm{S} / \mathrm{TCO} /$ glass: a new CdTe thin film solar cell structure. Sol. Energy Mater. Sol. Cell. 61, 203-211 (2000)

17. Peter, A.J., Lee, C.W.: Electronic and optical properties of CdS/ CdZnS nanocrystals. Chin. Phys. Soc. IOP Publ. 21(8), 087302 (2012)

18. Niemegeers, A., Burgelman, M., Decock, K., Verschraegen, J., Degrave, S.: SCAPS manual, Version. http://scaps.elis.ugent.be/. Accessed date 19 Dec 2016

19. Yang, K.J., Sim, J.H., Jeon, B., Son, D.H., Kim, D.H., Sung, S.J., Hwang, D.K., Song, S., Khadka, D.B., Kim, J., Kang, J.K.: Effects of $\mathrm{Na}$ and $\mathrm{MoS}_{2}$ on $\mathrm{Cu}_{2} \mathrm{ZnSnS}_{4}$ thin-film solar cell. Progr Photovolt. Res. Appl. 23(7), 862-873 (2014)

20. Fuhs, W.: Zinc oxide-a material for micro- and optoelectronic applications. NATO Sci. Ser. II Math. Phys. Chem. 194, 197-209 (2005)

21. Coutts, T.J., Mason, T.O., Perkins, J.D., Ginley, D.S.: Transparent conducting oxides: status and opportunities in basic research. Electrochem. Soc. Proc. 99-11, 274-289 (1999)

22. Peijie, L., Lingyan, L., Jinling, Y., Shuying, C., Peimin, L., Qiao, Z.: Numerical simulation of $\mathrm{Cu}_{2} \mathrm{ZnSnS}_{4}$ based solar cells with $\mathrm{In}_{2} \mathrm{~S}_{3}$ buffer layers by SCAPS-1D. J. Appl. Sci. Eng. 17(4), 383390 (2014)

23. Mahbub, R., Islam, M., Anwar, F., Satter, S.S., Ullah, S.M.: Simulation of CZTS thin film solar cell for different buffer layers for high efficiency performance. South Asian J. Eng. Technol. 2(52), $1-10$ (2016)

24. Mebarkia, C., Dib, D., Zerfaoui, H., Belghit, R.: Energy efficiency of a photovoltaic cell based thin films CZTS by SCAPS. J. Fundament. Appl. Sci. 8(2), 363-371 (2016)

25. Wanda, M.D., Ouédraogo, S., Tchoffo, F., Zougmoré, F., Ndjaka, J.M.B.: Numerical investigations and analysis of $\mathrm{Cu}_{2} \mathrm{ZnSnS}_{4}$ based solar cells by SCAPS-1D. Int. J. Photoenergy 2016, 2152018 (2016)

26. Green, M.A.: Solar Cells: Operating Principles, Technologies and System Applications, pp. 86-88. Eaglewood Cliffs, Prentice Hall (1982)

27. Dadu, M., Kapoor, A., Tripathi, K.N.: Effect of operating current dependent series resistance on the fill factor of a solar cell. Sol. Energy Mater. Sol. Cell. 71(2), 213-218 (2002)

28. Huang, J.Y., Lin, C.Y., Shen, C.H., Shieh, J.M., Da, B.T.: Low cost high-efficiency amorphous silicon solar cells with improved light-soaking stability. Sol. Energy Mater. Sol. Cell. 98, 277-282 (2012)

29. Green, M.A.: General temperature dependence of solar cell performance and implications for device modeling. Prog. Photovolt. Res. Appl. 11(5), 333-340 (2003)

Publisher's Note Springer Nature remains neutral with regard to jurisdictional claims in published maps and institutional affiliations. 